\title{
A SINGLE NUCLEOTIDE POLYMORPHISM POSSIBLY ASSOCIATED WITH FAT DEPOSITION IS METHYLATED IN THE BOVINE TFAM PROMOTER
}

\author{
Tanja KUNEJ ${ }^{1,2}$, Zeping WANG ${ }^{3}$, Jennifer J. MICHAL ${ }^{4}$, Peter DOVČ ${ }^{5}$, Nancy S. MAGNUSON ${ }^{6}$, \\ Zhihua JIANG ${ }^{7}$
}

Received November 02, 2016; accepted December 20, 2016. Delo je prispelo 02. novembra 2016, sprejeto 20. decembra 2016.

\begin{abstract}
A single nucleotide polymorphism possibly associated with fat deposition is methylated in the bovine TFAM promoter

Mitochondrial transcription factor A (TFAM) is a nuclear-encoded mitochondrial protein that plays an important role in energy metabolism and is a candidate gene for fat deposition in cattle and human. In the present study, we characterized the methylation status of bovine TFAM promoter flanking the single nucleotide polymorphism (SNP) rs42159487C >T, previously reported to affect fat deposition. Our results showed that the cytosine at this SNP position is methylated and therefore results in gain/loss of the functional CpG locus $\left(5^{\mathrm{m}} \mathrm{C}>\mathrm{T}\right)$. Promoter constructs developed based on three TFAM SNPs showed that the $\mathrm{C} / \mathrm{C} / \mathrm{C}$ haplotype associated with fat deposition in beef cattle had lower promoter function/activity than $\mathrm{A} / \mathrm{T} / \mathrm{T}$ haplotype. Our results imply that genetic variability underlying gain/loss of the CpG sites in the nuclear-encoded mitochondrial proteins might be good candidate loci for fat deposition phenotypes.

Key words: cattle; genetics; genetic polymorphism; candidate genes; gene promoters; TFAM; DNA methylation; CpG island; fat deposition
\end{abstract}

\section{INTRODUCTION}

Approximately $50 \%$ of gene transcripts encoding mitochondrial proteins decrease with the onset of obesity (Wilson-Fritch et al. 2003). One of these genes, mitochondrial transcription factor A (TFAM) is a strong
Polimorfno kandidatno mesto, povezano z nalaganjem maščobe, je metilirano $v$ promotorju gena TFAM pri govedu

Mitohondrijski transkripcijski faktor A (TFAM) je v jedru kodiran mitohondrijski protein, ki igra pomembno vlogo pri energetskem metabolizmu in je kandidatni gen za nalaganje maščobe pri govedu in človeku. V raziskavi smo opredelili metilacijski status promotorja gena TFAM pri govedu na polimorfnem mestu rs42159487C $>$ T, ki je bil v predhodnih objavah povezan $\mathrm{z}$ nalaganjem maščobe. Rezultati so pokazali, da je citozin na mestu tega polimorfizma metiliran in zato povzroča pridobitev/izgubo funkcionalnega CpG lokusa $(5 \mathrm{mC}>\mathrm{T})$. S promotorskim konstruktom, razvitim na osnovi treh polimorfizmov gena TFAM, smo dokazali, da je haplotip C/C/C, povezan $\mathrm{z}$ višjo vsebnostjo maščobe, imel nižjo promotorsko aktivnost v primerjavi s haplotipom A/T/T. Rezultati nakazujejo, da predstavlja genetska variabilnost, povezana s pridobitvijo/ izgubo CpG mest v jedru kodiranih mitohondrijskih proteinov, dobre kandidatne lokuse za študij genetskega ozadja nalaganja maščobe.

Ključne besede: govedo; genetika; genetski polimorfizem; kandidatni geni; promotorji genov; TFAM; metilacija DNA; CpG otok; nalaganje maščobe

candidate gene related to fat deposition in mammals (Jiang et al. 2005). In human medicine, TFAM was proposed to be one of the DNA markers and therapeutic targets for predisposition to obesity (Hudson, Lehnert, and Harper 2008) and is also included in the Obesity gene atlas in mammals (Kunej et al. 2013). Our previ-

\footnotetext{
1 University of Ljubljana, Biotechnical Faculty, Department of Animal Science, Groblje 3, SI-1230 Domžale, Slovenia

2 Corresponding author, e-mail: tanja.kunej@bf.uni-lj.si

3 Washington State University, School of Molecular Biosciences, Pullman, WA 99164-6525, USA, e-mail: zeping_wang@wsu.edu

4 Washington State University, Department of Animal Sciences, Pullman, WA 99164-6351, USA, e-mail: jennifer.michal@wsu.edu

5 Same address as 1, e-mail: peter.dovc@bf.uni-lj.si

6 Same address as 3, e-mail: magnuson@wsu.edu

7 Same address as 4, e-mail: jiangz@wsu.edu
} 
ous study showed significant associations of two closely linked TFAM promoter polymorphisms rs42159489A >C and $\mathrm{rs} 42159488 \mathrm{C}>\mathrm{T}$ with carcass, meat quality and fat deposition/composition in Wagyu $\mathrm{x}$ Limousin $\mathrm{F}_{2}$ crosses (Jiang et al. 2005). Additionally, a third mutation rs42159487C $>\mathrm{T}$ transition was also detected in the bovine TFAM promoter region, which showed significant association with beef marbling score (BMS), subcutaneous fat depth (SFD), and polyunsaturated fatty acids (PUFA) (Jiang et al., 2006). Since the third TFAM gene polymorphism rs42159487C $>$ T resides within a CG dinucleotide of the promoter region we aimed this study to determine the methylation status of the CG dinucleotide to discover if gain/loss of the DNA methylation could be a causative factor associated with fat deposition traits in cattle. Moreover, promoter activities of four constructs developed on haplotype information for these three TFAM promoter SNPs were also analyzed.

\section{MATERIALS AND METHODS}

Methylation status of the TFAM promoter was analyzed by bisulfite sequencing. For the bisulfite conversion, DNA was extracted from cattle muscle tissues using the GenElute Mammalian Genomic DNA Purification kit (Sigma-Aldrich, St. Louis, MO, USA). Bisulfite treatment was carried out using the EZ DNA methyla-

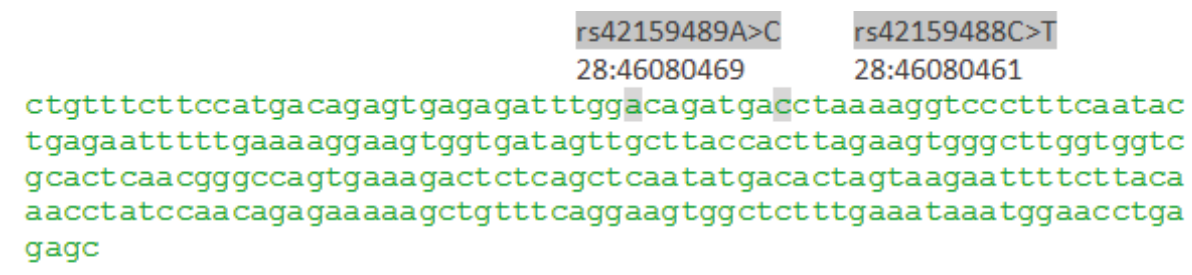

rs42159487C >T

28:46080243

tagaagcgtccttagatagcttagataaggttatcctaatctttttcatgccattgtcca

$28: 46080175 \quad 28: 46080162$

catggaaatggcggtactgcacatcgatcaatatctcaaggcataattgtcacaggttctc

28:46080101 28:4608088

agagctttggttgggaaatgatctcgtccaacatcctcgtctgcagtgggggaaattaaatc

Figure 1: Nucleotide sequence of the 5' upstream and exon 1 region of the bovine TFAM gene. Promoter, 5' UTR, coding exon 1 and partial intron 1 are marked in green, violet, black and blue, respectively. Cp G dinucleotides analyzed in this study are underlined and SNPs are highlighted in gray.

Slika 1: Nukleotidno zaporedje 5' konca gena za TFAM pri govedu. Promotor je obarvan zeleno, 5' neprevedena regija vijolično, kodirajoči del prvega eksona črno in del introna 1 modro. Cp G dinukleotidi, ki smo jih proučevali v tej študiji, so podčrtani in polimorfizmi posameznih nukleotidov so poudarjeni s sivo bravo. 

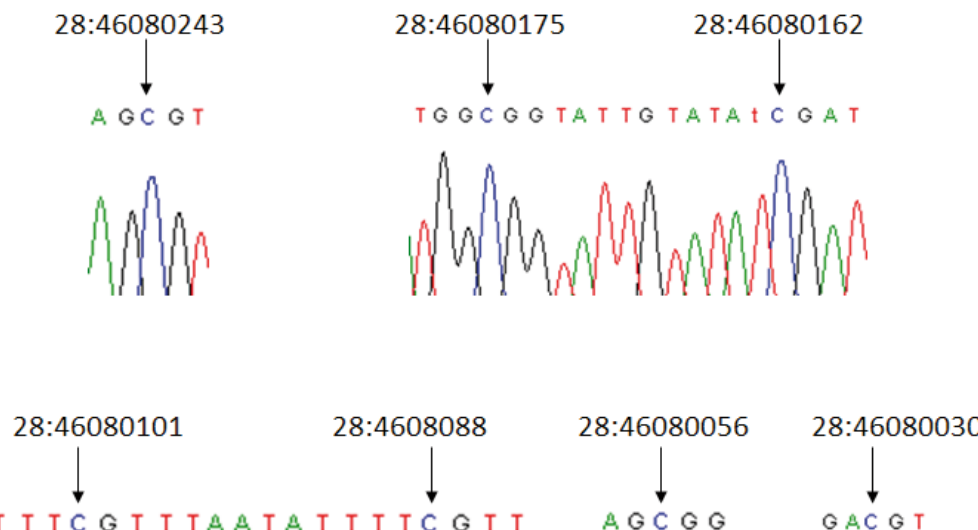

A

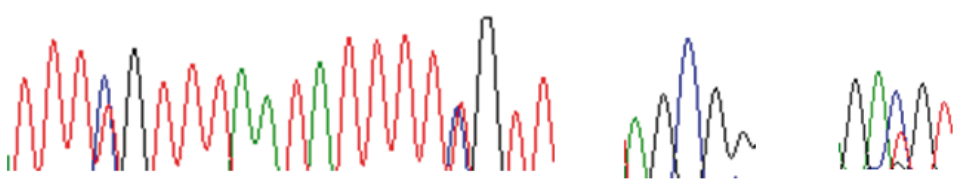

B

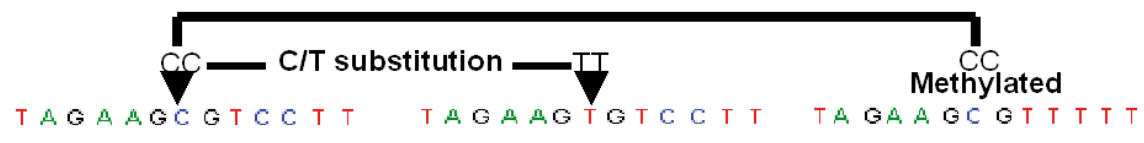

No bisulfite treatment

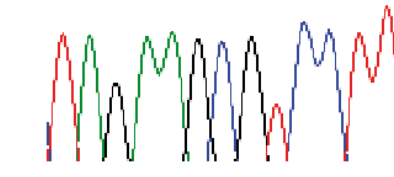
No bisulfite treatment
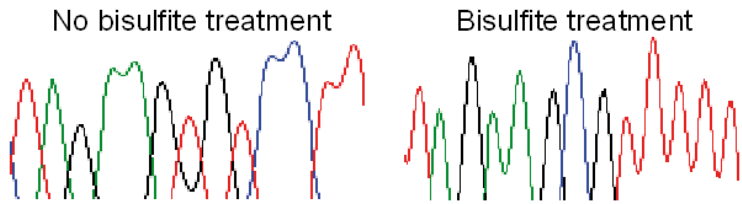

Figure 2: Determining the methylation status of seven TFAM promoter CpG loci in cattle. A: Four CpG dinucleotides in which the cytosine residues are methylated are on genomic locations 28:46080243, 28:46080175, 28:46080162 and 28:46080056. Three cytosines showed hemimethylated DNA status: 28:46080101, 28:46080088 and 28:46080030. B. CpG site and its methylation status due to rs42159487C $>$ T substitution in the bovine TFAM promoter. Sequence for the genotype CC, genotype TT and bisulfite treated DNA. Slika 2: Določitev metilacijskega statusa sedmih CpG motivov v promotorju gena za TFAM. A. Štirje CpG dinukleotidi, v katerih je citozim metiliran, so na genomskih lokacijah 28:46080243, 28:46080175, 28:46080162 in 28:46080056. Trije citozini kažejo hemimetiliran status: 28:46080101, 28:46080088 in 28:46080030. B. CpG mesto in njegov metilacijski status glede na subsititucijo na mestu rs 42159487C >T v promotorju gena za TFAM pri govedu. Zaporedja predstavljajo genotipa CC in TT ter $z$ bisulfitno reakcijo tretirano DNA.

tion kit (Zymo Research, Orange, CA, USA) according to the manufacturer's instructions. Two pairs of primers for bisulfite-sequencing PCR (BSP) of the TFAM promoter were designed using the MethPrimer tool (Li \& Dahiya, 2002) (http://www.urogene.org/methprimer/index1. html):

Meth1F: 5'-GTTGTTTTAGGAAGTGGTTTTTTGA-3', Meth1R:5'-ATAAAATTTAATTTCCCCCACTACAA-3', Meth2F: 5'-ATGTTATTGTTTATATGGAAAATGG-3' Meth2R 5'-AAAACTAAAATTCTAACTCCATCATT-3'. Bisulfite treated DNA was amplified in a final volume of $10 \mu \mathrm{L}$ that contained $12.5 \mathrm{ng}$ of each primer, $150 \mu \mathrm{M}$ dNTPs, $1.5 \mathrm{mM} \mathrm{MgCl}$, $50 \mathrm{mM} \mathrm{KCl}, 20 \mathrm{mM}$ Tris- $\mathrm{HCl}$ and $0.25 \mathrm{U}$ of Platinum Taq polymerase (Invitrogen, Carlsbad, CA, USA). The PCR conditions were as fol- lows: $94{ }^{\circ} \mathrm{C}$ for $2 \mathrm{~min}, 32$ cycles of $94^{\circ} \mathrm{C}$ for $30 \mathrm{sec}, 63^{\circ} \mathrm{C}$ for $30 \mathrm{sec}$ and $72^{\circ} \mathrm{C}$ for $30 \mathrm{sec}$, followed by final $5 \mathrm{~min}$ extension at $72^{\circ} \mathrm{C}$. PCR products were then sequenced for polymorphism detection on an ABI 3730 sequencer in the Laboratory for Biotechnology and Bioanalysis (Washington State University, Pullman, WA, USA) using a standard protocol.

The effects of SNPs on promoter activities were examined using a Dual-Luciferase Report Assay System (Promega, Madison, WI, USA). The data were analyzed using SAS MIXED procedure (Version 9.1; SAS Institute, Inc., Cary, NC, USA) based on the following linear model:

$y_{i j k}=h_{i}+p_{j}+e_{i j k}$ 
where $y_{i j k}=$ ratio of the $\mathrm{i}$-th haplotype in the k-th replication of the $\mathrm{j}$-th experiment, $h_{i}=$ fixed effect of the $\mathrm{i}$-th haplotype, $p_{j}=$ random effect of the $\mathrm{j}$-th experiment, and $e_{i j k}=$ residual. The overall mean is not included in the model, in order to ensure all unknown parameters in the model could be identified (i.e. all parameters are estimated uniquely). Technical details on the assembling of the promoter constructs are described as reported previously (Jiang et al., 2007; Kunej et al., 2007).

\section{RESULTS AND DISCUSSION}

We analyzed methylation status of $\sim 250 \mathrm{bp}$ of the cattle distal TFAM promoter (nucleotides approximately 28:46080000-28:46080243) flanking the cytosine residing at the polymorphism rs $42159487 \mathrm{C}>\mathrm{T}$ (previously named AAFC03078788.1 g.11650C >T) (Figure 1). The DNA extracted from the muscle and recovered after the bisulfite modification was amplified by PCR and sequenced directly. The methylated cytosines remained intact while the unmethylated cytosines were completely converted into uracil following bisulfite treatment and detected as thymine following PCR (Figure 2A). The analysis showed that at $\mathrm{r} s 42159487 \mathrm{C}>\mathrm{T}$ the cytosine is methylated and that genetic variation $\mathrm{C}>\mathrm{T}$ causes gain/ loss of the CPG locus. Sequences for the rs42159487 genotype CC, genotype TT and bisulfite treated DNA are shown in Figure 2B. We analyzed bisulfite treated muscle DNA from six animals with rs42159487 C/C and six animals with $\mathrm{C} / \mathrm{T}$ genotype; in all cases the bisulfite sequencing showed methylation of the cytosine. Additionally, we determined the methylation status for six adjacent $\mathrm{CpGs}$;

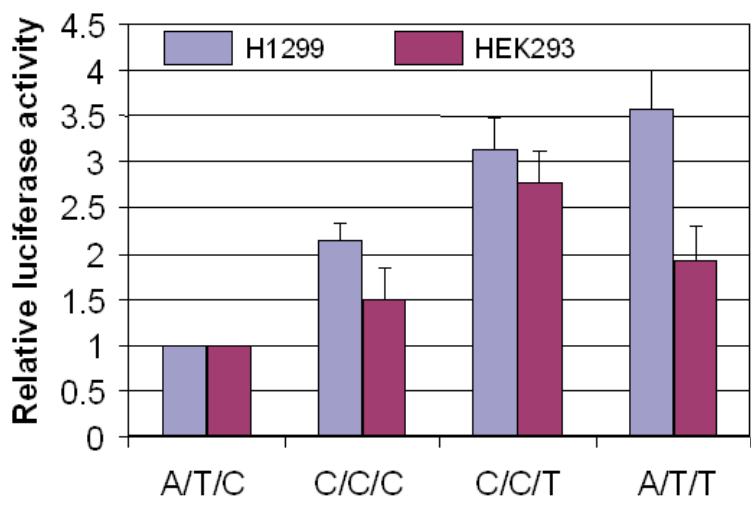

Figure 3: Promoter activities of four constructs representing haplotypes containing three TFAM promoter SNPs: rs42159489A>C, $r s 42159488 C>T$, and $r s 42159487 C>T$ in $\mathrm{H} 1299$ and HEK293 cells Slika 3: Aktivnost promotorja $v$ štirih konstruktih, ki predstavljajo haplotipe s tremi polimorfnimi mesti v promotorju gena TFAM three of them had methylated and three hemimethylated DNA status (Figure 2A).

Four promoter constructs were developed based on haplotypes among three cattle TFAM promoter SNPs: $\mathrm{A} / \mathrm{T} / \mathrm{C}, \mathrm{C} / \mathrm{C} / \mathrm{C}, \mathrm{C} / \mathrm{C} / \mathrm{T}$, and A/T/T. As shown in Figure 3, these constructs had different promoter activity patterns in two cell lines: H1299 and HEK293. H1299 cell line was selected as a highly proliferative cell line, which is widely used in research due to its high rate of transgene expression, whereas HEK293 cell line was selected because of its propensity for transfection. In the Wagyu $\times$ Limousin $\mathrm{F}_{2}$ population, we found that $\mathrm{C} / \mathrm{C} / \mathrm{C}$ and $\mathrm{A} / \mathrm{T} / \mathrm{T}$ are the two major haplotypes (Jiang et al., 2009). In general, the former haplotype had lower promoter activity compared to the latter haplotype and the difference among cell lines was more pronounced in the $\mathrm{A} / \mathrm{T} / \mathrm{T}$ haplotype. However, the former haplotype is associated with high marbling score and SFD, while the latter haplotype reduces the expression of both traits. In addition, the substitution rs42159487C $>$ T causes gain/loss of a CpG site. When the aforementioned $\mathrm{CpG}$ site is present, it is methylated. These results indicate that reduced promoter function/ activity of the bovine TFAM might be associated with more fat in beef cattle. Therefore, change of TFAM gene expression is consistent with beef marbling or intramuscular fat accumulation. The methylation status of this locus should also be tested in other cattle breeds, tissues and developmental stages. Additional functional studies should be performed, for instance estimating the mitochondrial content through mitochondrial copy number.

\section{ACKNOWLEDGEMENT}

This work was supported by Agricultural Research Center, Washington State University and the Slovenian Research Agency (ARRS) (program P4-0220).

\section{REFERENCES}

Hudson, N. J., Lehnert, S. A., \& Harper, G. S. (2008). Obese humans as economically designed feed converters: symmorphosis and low oxidative capacity skeletal muscle. Med Hypotheses, 70(3), 693-7. doi:10.1016/j.mehy.2007.05.042

Jiang, Z., Kunej, T., Wibowo, T. A., Michal, J. J., Zhang, Z., Gaskins, C. T., ... Wright, R. W. jr. (2006). The basal nucleusencoded mitochondrial transcription genes and meat quality in beef cattle. In Proceedings of the $8^{\text {th }}$ World Congress on Genetics Applied to Livestock Production (pp. 22-24).

Jiang, Z., Kunej, T., Michal, J. J., Gaskins, C. T., Reeves, J. J., Busboom, J. R., ... Wright, R. W. (2005). Significant associations of the mitochondrial transcription factor A promoter polymorphisms with marbling and subcutaneous fat depth in 
Wagyu $\times$ Limousin F2 crosses. Biochemical and Biophysical Research Communications, 334(2), 516-523. doi:10.1016/j. bbrc.2005.06.120

Jiang, Z., Michal, J. J., Chen, J., Daniels, T. F., Kunej, T., Garcia, M. D., ... Macneil, M. D. (2009). Discovery of novel genetic networks associated with 19 economically important traits in beef cattle. International Journal of Biological Sciences, 5(6), 528-542. doi:10.7150/ijbs.5.528

Jiang, Z., Wang, Z., Kunej, T., Williams, G. A., Michal, J. J., Wu, X. L., \& Magnuson, N. S. (2007). A novel type of sequence variation: multiple-nucleotide length polymorphisms discovered in the bovine genome. Genetics, 176(1), 403-407. doi:10.1534/genetics.106.069401

Kunej, T., Jevšinek Skok, D., Zorc, M., Ogrinc, A., Michal, J. J., Kovač, M., \& Jiang, Z. (2013). Obesity gene atlas in mammals. Journal of Genomics, 1, 45-55. doi:10.7150/jgen.3996
Kunej, T., Wang, Z., Michal, J. J., Daniels, T. F., Magnuson, N. S., \& Jiang, Z. (2007). Functional UQCRC1 polymorphisms affect promoter activity and body lipid accumulation. Obesity (Silver Spring), 15(12), 2896-2901. doi:10.1038/ oby.2007.344

Li, L. C., \& Dahiya, R. (2002). MethPrimer: designing primers for methylation PCRs. Bioinformatics, 18(11), 1427-1431. doi:10.1093/bioinformatics/18.11.1427

Wilson-Fritch, L., Burkart, A., Bell, G., Mendelson, K., Leszyk, J., Nicoloro, S., ... Corvera, S. (2003). Mitochondrial biogenesis and remodeling during adipogenesis and in response to the insulin sensitizer rosiglitazone. Molecular and Cellular Biology, 23(3), 1085-1094. doi:10.1128/MCB.23.3.10851094.2003 